\title{
Polychaete fauna in the vicinity of bluefin tuna sea-cages in Ensenada, Baja California, Mexico
}

\author{
VICTORIA DÍAZ-CASTAÑEDA ${ }^{1} \&$ SANTIAGO VALENZUELA-SOLANO \\ CICESE Department of Ecology Km 107 Carr. Tijuana-Ensenada \\ Ap. Postal 2732 C.P. 22860 Ensenada, Baja California, Mexico. \\ 'Corresponding author.E-mail: vidiaz@cicese.mx
}

\begin{abstract}
This paper describes the polychaete fauna in Salsipuedes Bay, Baja California. Sea-cage farming results in a rain of organic matter onto the underlying benthos. There is growing concern over the effects of tuna sea-cages on the local sediment chemistry and benthic communities. Eighteen stations were sampled with a Van Veen grab $\left(0.1 \mathrm{~m}^{2}\right)$ from the oceanographic vessel Francisco de Ulloa in March 2003 and October 2004. Redox potential in 2003 ranged between -113 and $-200 \mathrm{mV}$, while in 2004 it ranged between -110 and $-302 \mathrm{mV}$. Organic carbon concentrations varied between $0.20 \%$ and $2.53 \%$, lowest values were located in the southern part of the bay; highest concentrations were found at stations $18-22$ situated in the northern section, west of the tuna pens. Organic $\mathrm{N}$ varied between $0.02 \%$ and $0.12 \%$, highest concentrations $(0.07-0.12 \%)$ were located at stations $16-21$ in the northern section of the bay; stations situated at the south and near the coast presented the lowest $\mathrm{N}$ concentrations $(0.02-0.04 \%)$.

A total of 9,291 organisms belonging to seven phyla were collected: Polychaeta, Mollusca, Crustacea, Echinodermata, Cnidaria, Sipuncula, and Bryozoa. Polychaetes accounted for $62 \%$ of all invertebrate macrofauna, with 5,765 specimens representing 34 families and 146 species. The best represented families in 2003 and 2004 were Paraonidae, Cirratulidae, Spionidae, Capitellidae, Syllidae, Nephtyidae, Lumbrineridae, and Glyceridae.

Polychaetes were dominant at almost all sampling stations. Families with the highest species richness were Paraonidae (14 spp.), Spionidae (11 spp.), Onuphidae (11 spp.), Maldanidae (10 spp.), Syllidae (9 spp.), Cirratulidae and Ampharetidae with 7 species each. Among the most abundant species were Aphelochaeta multifilis, Mediomastus ambiseta, Prionospio steenstrupi Spiophanes bombyx, Apoprionospio pygmaea, Paraonella sp., Monticellina sp., Aricidea (Allia) ramosa, Spiophanes bombyx, Spiophanes duplex, and Levinsenia gracilis. The dominant trophic group was deposit-feeders, followed by carnivores.

In 2003 Shannon index varied between 2.26 and 3.40 bits/ind.; the highest diversity values were found in the southern section of Salsipuedes Bay. In 2004 diversity fluctuated between 2.31and 3.35; the highest values were found at three stations in the northern section south of the tuna pens. Stress-predictability modeling characterized $85 \%$ of stations in 2003 and $78 \%$ in 2004 as presenting favorable and stable conditions, the rest were considered moderately disturbed. Non-metric multidimensional scaling (MDS) separated stations depending on the distance to the tuna pens. Our results indicate that Salsipuedes Bay is still a favorable environment for polychaetes. Apparently local circulation has at least partially dispersed the excess organic matter.
\end{abstract}

Key words: tuna farming, benthos, organic carbon, deposit feeders, Pacific 


\section{Introduction}

Polychaetes are one of the dominant components of soft-bottom communities; they are diverse, abundant, and ecologically significant functional constituents of coastal ecosystems, exhibiting a high adaptability to different habitats. These worms are an essential part of food webs, multiplying trophic connections with their richness, abundance, and diverse feeding strategies, and they serve as important descriptors of environmental conditions (Sarkar et al. 2005). In Baja California, tuna fattening mariculture is expanding rapidly and there are increasing concerns about possible ecological impacts in the coastal zone. Up to now, no studies have been published and little information is available for an environmental impact assessment of tuna ranching. Scientists have pointed out the importance of minimizing negative impacts in the marine environment in order to have a sustainable industry. It is therefore essential not to exceed the environmental capacity to process excess organic matter (Karakassis et al. 2000). Mexican tuna farming operations currently represent nearly $10 \%$ of world production (Rojas \& Wadsworth 2007).

The production of marine fish in cages takes place in several countries worldwide and is still expanding, for example in the Nordic countries (Enell 1995) and Asia (Liao \& Lin 2000). In Mexico it is becoming an increasingly important economic activity. Once considered an environmentally benign practice, it is now viewed as a potential polluter of the marine environment. The particulate organic waste in the form of uneaten food and feces are generally the most significant wastes generated in this activity. This organic material accumulates on the seafloor, providing a net input of organic carbon and nitrogen to the sediments, which may induce high biological oxygen demand and potentially anoxic conditions causing major modifications in the benthic community (Grall \& Chavaud 2002, Shahidul 2005). It is important for producers to maintain good environmental conditions in their concession sites in order to assure the success and sustainability of their activity.

It is necessary to assess the effects of human activities on coastal areas. This research will help elucidate the environmental changes caused by this activity, in particular those associated with the enrichment of the seafloor. Pollution from tuna farms bring changes in the physical and chemical properties of benthic habitats (negative redox values, high organic content), resulting in changes in the composition of benthic assemblages (Hall et al., 1992; Karakassis et al. 1998).

Benthic communities have been extensively used in monitoring the effects of marine pollution as the organisms are mostly sessile and integrate effects of pollutants over time (Gray et al. 1990). Polychaetes respond to cumulative factors of natural and anthropogenic origin and therefore are useful for detecting environmental alterations.

Bahía Salsipuedes is a small, open bay located $15 \mathrm{~km}$ north of Ensenada (Fig. 1); it has an area of approximately $30 \mathrm{~km}^{2}$ and water depth varies from 10 to $100 \mathrm{~m}$. Tuna have been cultured there since autumn 2002. Each tuna farming concession can install up to 16 tuna pens, each of which is $40 \mathrm{~m}$ in diameter, about $20 \mathrm{~m}$ deep, and has a volume of $18,850 \mathrm{~m}^{3}$; stocking density is about $40-45$ tons per cage. The animals are kept for 4-5 months and fed twice/day for six days per week mainly with sardines and mackerel. The daily food ration is about $7-8 \%$ of the biomass in the pen.

\section{Materials and methods}

Sediment samples were taken at 18 stations (Fig. 1, Table 1) using a 0.1- $\mathrm{m}^{2}$ Van Veen grab; the closest to the tuna pens we could sample was $250 \mathrm{~m}$. The redox potential was measured immediately after collection of each sample by probing $2 \mathrm{~cm}$ into the sediments with an Ingold electrode coupled to a field potentiometer and a thermometer. Sediments were sieved using $1.0-\mathrm{mm}$ mesh and retained 
material was fixed in a $7 \%$ buffered sea-water-formalin solution. In the laboratory, samples were washed using a $0.5-\mathrm{mm}$-mesh sieve and transferred to $70 \%$ ethanol. Macrofaunal organisms were sorted and counted; polychaetes were identified to species level whenever possible, using stereo and light microscopy, and different taxonomic keys (Blake 1995; Blake \& Hilbig 1994; Blake et al. 1995, 1996; Fauchald 1977; Hilbig 1994; Knox 1977; Salazar-Vallejo \& Salaices-Polanco 1989).

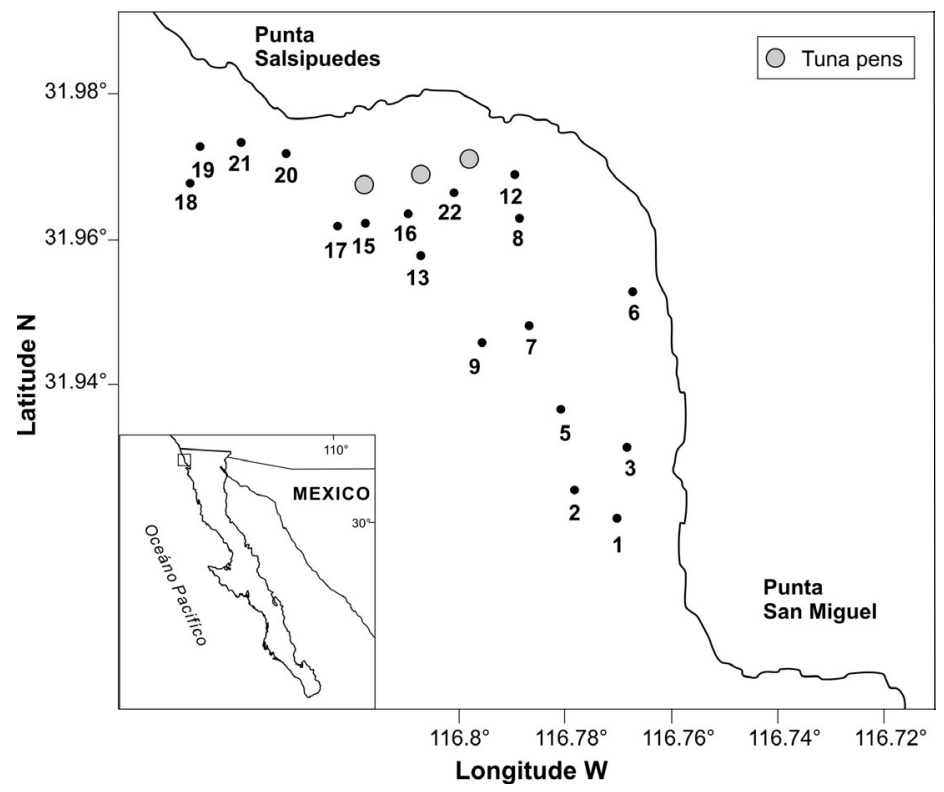

FIGURE 1. Geographic distribution of sampling sites and tuna pens at Salsipuedes Bay, northern Baja California.

Physicochemical data of the water column were obtained using a CTD at each station. Environmental measurements included depth $(\mathrm{m})$, temperature $\left({ }^{\circ} \mathrm{C}\right)$, salinity $(\% \circ)$, and dissolved oxygen $(\mathrm{ml} / \mathrm{l})$.

In 2003 total organic matter content was determined by ignition loss (Dean 1974; Byers et al. 1978). In 2004 organic carbon and nitrogen were evaluated using the method of Hedges \& Stern (1984) with an Elemental Analyzer LECO CHNS-932. Granulometry was determined by means of a Laser Horiba LA 910.

Statistical methods were used to describe the polychaete assemblages in Salsipuedes. The most commonly used diversity index, Shannon or H' (Shannon \& Weaver 1963), was calculated together with Pielou's (1977) evenness index in order to study the structure and degree of organization of the polychaete communities (Frontier 1985). Trophic groups were determined using Fauchald \& Jumars (1979) and Rouse \& Pleijel (2001).

Olmstead and Tukey's test (Sokal \& Rohlf 1995) was applied to analyze the spatial distribution of polychaetes within the study area. This technique plots the frequency of appearance of each family in each site sampled expressed as a percentage of the density of organisms for each family. A mean average was calculated for both axes, resulting in four quadrants: I, frequent and abundant species (Dominant); II, nonfrequent and abundant species (Restricted); III, nonfrequent and nonabundant species (Rare); and IV Frequent and nonabundant species. 
TABLE 1. Geographic location and depth of stations.

\begin{tabular}{llll}
\hline Station & Longitude $(\mathbf{N})$ & Latitude $(\mathbf{W})$ & Depth $(\mathbf{m})$ \\
\hline 1 & $116^{\circ} 77^{\prime}$ & $31^{\circ} 92^{\prime}$ & 47 \\
2 & $116^{\circ} 78^{\prime}$ & $31^{\circ} 93^{\prime}$ & 63 \\
3 & $116^{\circ} 77^{\prime}$ & $31^{\circ} 93^{\prime}$ & 37 \\
5 & $116^{\circ} 78^{\prime}$ & $31^{\circ} 94^{\prime}$ & 66 \\
6 & $116^{\circ} 77^{\prime}$ & $31^{\circ} 95^{\prime}$ & 20 \\
7 & $116^{\circ} 79^{\prime}$ & $31^{\circ} 95^{\prime}$ & 62 \\
8 & $116^{\circ} 79^{\prime}$ & $31^{\circ} 96^{\prime}$ & 38 \\
9 & $116^{\circ} 79^{\prime}$ & $31^{\circ} 97^{\prime}$ & 72 \\
12 & $116^{\circ} 80^{\prime}$ & $31^{\circ} 95^{\prime}$ & 30 \\
13 & $116^{\circ} 81^{\prime}$ & $31^{\circ} 96^{\prime}$ & 59 \\
15 & $116^{\circ} 82^{\prime}$ & $31^{\circ} 96^{\prime}$ & 55 \\
16 & $116^{\circ} 81^{\prime}$ & $31^{\circ} 96^{\prime}$ & 49 \\
17 & $116^{\circ} 82^{\prime}$ & $31^{\circ} 96^{\prime}$ & 65 \\
18 & $116^{\circ} 85^{\prime}$ & $31^{\circ} 97^{\prime}$ & 92 \\
19 & $116^{\circ} 85^{\prime}$ & $31^{\circ} 97^{\prime}$ & 76 \\
20 & $116^{\circ} 83^{\prime}$ & $31^{\circ} 97^{\prime}$ & 38 \\
21 & $116^{\circ} 84^{\prime}$ & $31^{\circ} 97^{\prime}$ & 30 \\
22 & $116^{\circ} 80^{\prime}$ & $31^{\circ} 97^{\prime}$ & 41 \\
\hline
\end{tabular}

Stress predictability modeling (Alcolado 1992) was applied to establish the level of environmental stress existing in different parts of the bay. Environmental severity or stress was predicted based on values of diversity $\left(\mathrm{H}^{\prime}\right)$ and evenness $\left(\mathrm{J}^{\prime}\right)$, coupled with redox potential values.

Ordination and classification methods were used to detect spatial patterns among the polychaete fauna. Cluster analysis using Sorensen, Jaccard, and Bray-Curtis similarity coefficients (Bray \& Curtis 1957; Sokal \& Rohlf 1995) were employed to evaluate the level of association of different sampling sites (stations). The raw data were transformed by using $\log (\mathrm{x}+1)$ as suggested by Frontier (1985) and Legendre \& Legendre (1984). Nonmetric Multidimensional Scaling (MDS) was used for the community ordination using PRIMER 5, since this technique has been demonstrated to be suitable for multiple ecological purposes (Clarke 1993). It is based on an association matrix containing the similarities between all pairs of samples; when samples are close to each other, they have more similar faunistic profiles. The quality of this representation is measured by the "stress" value. The lower this value the better the representation. A high stress value indicates a higher dimensionality of the data (Clarke \& Warwick 1994) and is typical for samples that do not contain a clear structure. One data matrix was created for each sampling period using abundance per species.

Similarity was measured by the Bray-Curtis coefficient on square-root transformed abundance data. The triangular similarity matrices were then subjected to non-metric multi-dimensional scaling (MDS) ordination. The MDS ordination was used to examine the data and compare community composition in different areas of Salsipuedes Bay. 
The technique of principal component analysis (PCA) is based on the calculation of vectors or principal components. This technique can summarize in some dimensions most of the variability of a matrix with many descriptors and allows us to know the percentage of variance explained by the axes. In order to understand which environmental variables had more influence on polychaetes structure, a PCA analysis was made with the following variables: organic carbon content, organic nitrogen content sediment grain size $(<63 \mu)$, redox potential $(\mathrm{mV})$, dissolved oxygen $(\mathrm{ml} / \mathrm{l})$, biomass, and abundance.

\section{Results}

In 2003 temperature near the seabed varied between $11.2^{\circ} \mathrm{C}$ and $12.9^{\circ} \mathrm{C}$, while in 2004 it varied between $11.0^{\circ} \mathrm{C}$ and $13.3^{\circ} \mathrm{C}$; in general, deeper stations presented lower temperature values. Salinity in 2003 varied between $33.5 \%$ and $33.8 \%$ ond in 2004 between $33.2 \%$ and $33.6 \%$. Oxygen values are available only for 2004; the lowest oxygen concentration $(2.99 \mathrm{ml} / \mathrm{l})$ was at station $18(86 \mathrm{~m}$ depth) northwest of Salsipuedes, the highest value $(4.86 \mathrm{ml} / \mathrm{l})$ was found in the middle of the bay, near the coast (station 6) at $20 \mathrm{~m}$ depth.
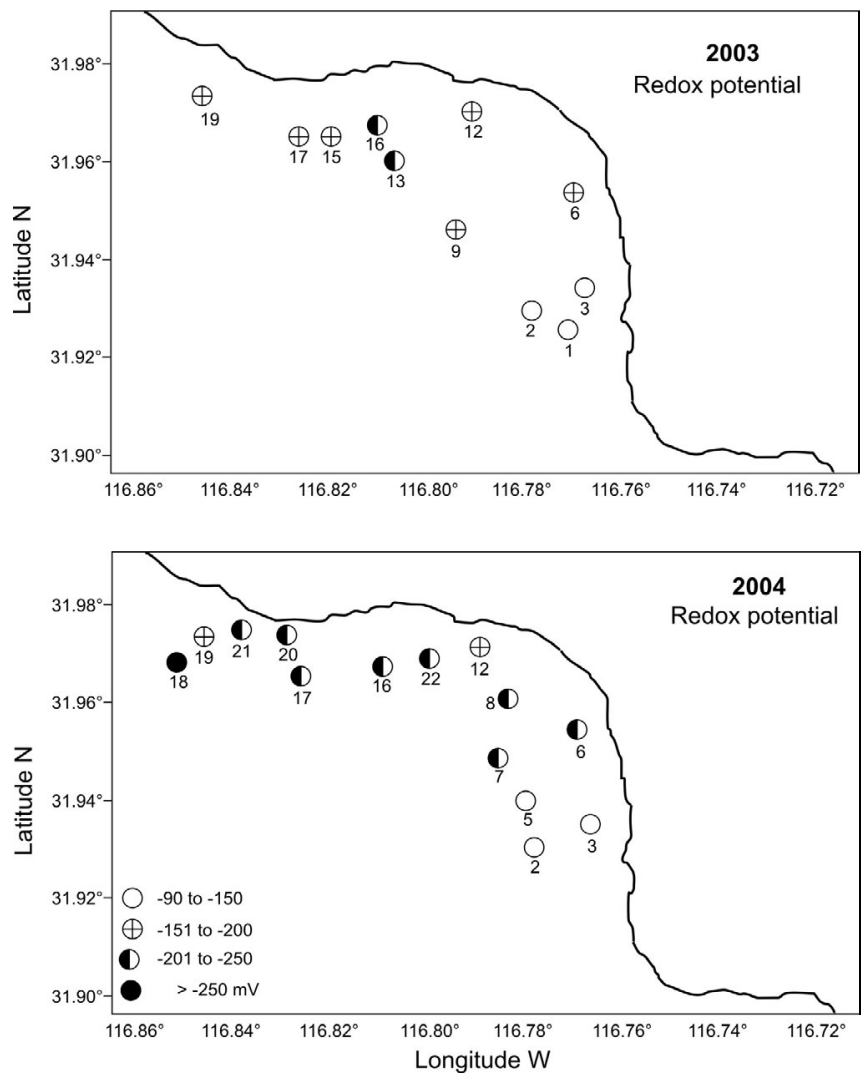

FIGURE 2. Redox potential values (Eh) in 2003 and 2004. 
Redox potential values (Eh) were negative at most of the stations (Fig. 2); they reached higher negative values in 2004. In 2003 values varied between $-113 \mathrm{mV}$ and $-210 \mathrm{mV}$; while in 2004 values varied between -110 and $-302 \mathrm{mV}$.

\section{$\mathrm{C}$ and $\mathrm{N}$ values}

Unfortunately the frozen sediment samples from 2003 were lost and we have values for organic matter for only five stations $(1,2,6,13,15)$. Organic matter values varied between 0.7 to $3.6 \%$, the lowest concentration was found in station 2 and the highest at station 13.

In 2004, organic C concentrations oscillated between $0.20 \%$ and $2.53 \%$ (Fig. 3); the lowest values were found in the southern part of the bay and the highest concentrations were found at stations 18-22 located in the northern section where the tuna pens were located.

Organic $\mathrm{N}$ varied between $0.02 \%$ and $0.12 \%$; the highest concentrations $(0.07-0.12 \%)$ were found at stations 16-21 in the northern section of the bay. Stations 3, 6, 8, and 12 situated in the south and near the coast presented the lowest concentrations $(0.02-0.04 \%)$.
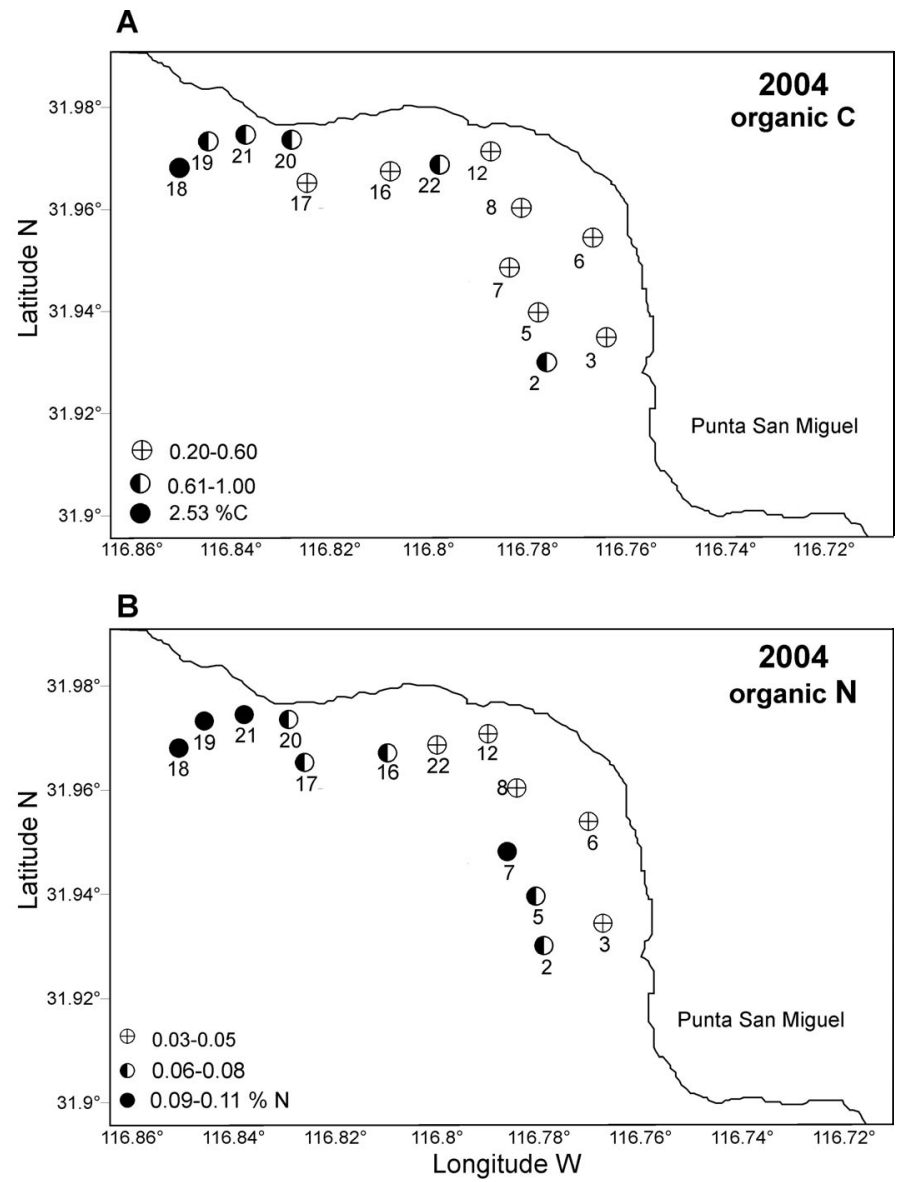

FIGURE 3. Organic carbon and organic nitrogen concentrations in 2004. 


\section{Species richness}

Organisms belonging to seven phyla were collected: Polychaeta, Crustacea, Mollusca, Echinodermata, Sipuncula, Bryozoa, and Cnidaria. A total of 9,291 organisms were collected in 2003 and 2004. Analysis of the benthic samples demonstrated that $62.2 \%$ of all invertebrate macrofauna were polychaetes, with 5,765 specimens representing 34 families and 146 species (Tables 2-3). Polychaetes were dominant in almost all sampling stations, except station 12 in 2003 and stations 2 and 6 in 2004, when peracarid crustaceans were dominant.

TABLE 2. Polychaete families collected in 2003 and 2004 in Salsipuedes Bay.

\begin{tabular}{|c|c|c|}
\hline Family & 2003 & 2004 \\
\hline Ampharetidae Malmgren, 1866 & $\mathrm{X}$ & $\mathrm{X}$ \\
\hline Capitellidae Grube, 1862 & $\mathrm{X}$ & $\mathrm{X}$ \\
\hline Cirratulidae Ryckholt, 1851 & $\mathrm{X}$ & $\mathrm{X}$ \\
\hline Cossuridae Day, 1963 & $\mathrm{X}$ & \\
\hline Dorvilleidae Chamberlain, 1919 & $\mathrm{X}$ & \\
\hline Eunicidae Berthold, 1827 & $\mathrm{X}$ & $\mathrm{X}$ \\
\hline Flabelligeridae Saint-Joseph, 1894 & & $\mathrm{X}$ \\
\hline Glyceridae Grube, 1850 & $\mathrm{X}$ & $\mathrm{X}$ \\
\hline Goniadidae Kinberg, 1866 & $\mathrm{X}$ & $\mathrm{X}$ \\
\hline Hesionidae Grube, 1850 & $\mathrm{X}$ & $\mathrm{X}$ \\
\hline Lumbrineridae Schmarda, 1861 & $\mathrm{X}$ & $\mathrm{X}$ \\
\hline Magelonidae Cunningham \& Ramage, 1888 & $\mathrm{X}$ & $\mathrm{X}$ \\
\hline Maldanidae Malmgren, 1867 & $\mathrm{X}$ & $\mathrm{X}$ \\
\hline Nephtyidae Grube, 1850 & $\mathrm{X}$ & $\mathrm{X}$ \\
\hline Nereididae Johnston, 1899 & $\mathrm{X}$ & $\mathrm{X}$ \\
\hline Oenonidae Kinberg, 1856 & $\mathrm{X}$ & $\mathrm{X}$ \\
\hline Onuphidae Kinberg, 1865 & $\mathrm{X}$ & $\mathrm{X}$ \\
\hline Orbiniidae Hartman, 1942 & $\mathrm{X}$ & $\mathrm{X}$ \\
\hline Oweniidae Rioja, 1917 & $\mathrm{X}$ & $\mathrm{X}$ \\
\hline Paraonidae Cerruti, 1909 & $\mathrm{X}$ & $\mathrm{X}$ \\
\hline Pholoidae Kinberg, 1858 & $\mathrm{X}$ & $\mathrm{X}$ \\
\hline Phyllodocidae Örsted, 1843 & $\mathrm{X}$ & $\mathrm{X}$ \\
\hline Pisionidae Southern, 1914 & $\mathrm{X}$ & \\
\hline Polynoidae Malmgren, 1867 & $\mathrm{X}$ & $\mathrm{X}$ \\
\hline Sabellariidae Johnston, 1867 & & $\mathrm{X}$ \\
\hline Sabellidae Malmgren,1867 & $\mathrm{X}$ & $\mathrm{X}$ \\
\hline Scalibregmatidae Malmgren, 1867 & & $\mathrm{X}$ \\
\hline Serpulidae Johnston, 1865 & & $\mathrm{X}$ \\
\hline Sigalionidae Malmgren, 1867 & $\mathrm{X}$ & $\mathrm{X}$ \\
\hline Spionidae Grube, 1850 & $\mathrm{X}$ & $\mathrm{X}$ \\
\hline Sternaspidae Carus, 1863 & $\mathrm{X}$ & $\mathrm{X}$ \\
\hline Syllidae Grube, 1850 & $\mathrm{X}$ & $\mathrm{X}$ \\
\hline Terebellidae Malmgren, 1867 & $\mathrm{X}$ & $\mathrm{X}$ \\
\hline Trichobranchidae Malmgren, 1866 & $\mathrm{X}$ & $\mathrm{X}$ \\
\hline
\end{tabular}


TABLE 3. Polychaete species collected in 2003 and 2004 at Salsipuedes Bay.

\begin{tabular}{|c|c|}
\hline Family and Species & Family and Species \\
\hline Ampharetidae & Goniadidae \\
\hline Ampharete acutifrons Grube, 1860 & Glycinde sp. \\
\hline Amphicteis glabra Moore, 1905 & Goniada littorea Hartman, 1950 \\
\hline Amphicteis labrops Hartman, 1961 & Goniada maculata Örsted, 1843 \\
\hline Asabellides lineata (Berkeley \& Berkeley, 1943) & Hesionidae \\
\hline Melinna oculata Hartman, 1969 & Micropodarke sp. \\
\hline Sabellides cf. manriquei Salazar-Vallejo, 1996 & Podarkeopsis glabra Hartman, 1961 \\
\hline Capitellidae & Podarkeopsis sp. \\
\hline Mediomastus acuta Hartman, 1969 & Lumbrineridae \\
\hline Mediomastus ambiseta Hartman, 1947 & Lumbrineris californiensis Hartman, 1944 \\
\hline Mediomastus californiensis Hartman, 1944 & Lumbrineris crassidentata Fauchald, 1970 \\
\hline Neonotomastus sp. & Ninoe tridentata Hilbig, 1995 \\
\hline Notomastus sp. & Scoletoma tetraura Schmarda, 1861 \\
\hline Cirratulidae & Magelonidae \\
\hline Aphelochaeta multifilis Moore, 1909 & Magelona hartmanae Jones, 1978 \\
\hline Aphelochaeta tigrina Blake, 1996 & Magelona pitelkai Hartman, 1944 \\
\hline Chaetozone corona Berkeley \& Berkeley, 1941 & Magelona sp. \\
\hline Chaetozone hartmanae Blake, 1996 & Maldanidae \\
\hline Chaetozone senticosa Blake, 1996 & Axiothella rubrocincta Johnson, 1901 \\
\hline Monticellina cryptica Blake, 1996 & Clymenella sp. \\
\hline Monticellina sp. & Clymenura gracilis Hartman, 1969 \\
\hline Cossuridae & Maldane sarsi Malmgren, 1865 \\
\hline Cossura brunnea Fauchald, 1972 & Notoproctus sp. \\
\hline Cossura candida Hartman, 1955 & Petaloclymene pacifica Green, 1997 \\
\hline Cossura sp. & Praxillella pacifica Berkeley, 1929 \\
\hline Dorvilleidae & Praxillella sp. \\
\hline Schistomeringos annulata (Moore, 1906) & Rhodine bitorquata Moore, 1923 \\
\hline Dorvillea sp. & Nephtyidae \\
\hline Eunicidae & Aglaophamus dicirris Hartman, 1945 \\
\hline Eunice cf. muitipectinata Moore, 1911 & Aglaophamus eugeniae Fauchald, 1972 \\
\hline Marphysa disjucta Hartman, 1961 & Aglaophamus verrilli McIntosh, 1885 \\
\hline Flabelligeridae & Nephtys caecoides Hartman, 1938 \\
\hline Brada villosa Rathke, 1843 & Nephtys californiensis Hartman, 1938 \\
\hline Pherusa neopapillata Hartman, 1961 & Nephtys sp. \\
\hline Pherusa sp. & Nereididae \\
\hline Glyceridae & Neanthes arenaceodentata (Moore, 1903) \\
\hline Glycera americana Leidy, 1855 & Neanthes cf. acuminata Ehlers, 1868 \\
\hline Glycera oxycephala Ehlers, 1887 & Nereis sp. \\
\hline Glycera sp. & Oenonidae \\
\hline Glycera tenuis Hartman, 1944 & Arabella iricolor Montagu, 1804 \\
\hline Glycera tesselata Grube, 1840 & Drilonereis mexicana Fauchald, 1970 \\
\hline
\end{tabular}


TABLE 3 (continued)

Family and Species

\section{Oenonidae}

Drilonereis sp.

Notocirrus californiensis Hartman 1944

\section{Onuphidae}

Diopatra ornata Moore, 1911

Diopatra tridentata Hartman, 1944

Hyalinoecia juvenalis Moore, 1911

Mooreonuphis nebulosa Moore, 1911

Mooreonuphis sp.

Nothria occidentalis Fauchald, 1968

Onuphis elegans Johnson, 1901

Onuphis iridescens Johnson 1901

Onuphis sp.

Paradiopatra parva Moore, 1911

Ramphobrachium longisetosum Berkeley \& Berkeley, 1938

\section{Orbiniidae}

Phylo felix Kinberg, 1866

Scoloplos acmeceps Chamberlin, 1919

\section{Oweniidae}

Myriochele gracilis Hartman, 1955

Myriochele sp.

Owenia collaris Hartman, 1955

\section{Paraonidae}

Aricidea (Aedicira) alisetosa Fauchald, 1972

Aedicira pacifica Hartman, 1944

Aricidea quadrilobata Webster \& Benedict, 1887

Aricidea (Allia) antennata Annenkova, 1934

Aricidea (Acmira) catherinae Laubier, 1967

Aricidea (Acmira) lopezi Berkeley \& Berkeley, 1956

Aedicira ramosa Annenkova, 1934

Aricidea (Acmira) simplex Day, 1963

Aricidea (Aricidea) wassi Pettibone, 1965

Paradoneis sp.

Cirrophorus furcatus Hartman, 1957

Levinsenia gracilis Tauber, 1897

Levinsenia oculata Hartman, 1957

Paraonella sp.

\section{Pholoidae}

Pholoe glabra Hartman, 1961

Phyllodocidae

Eulalia californiensis Hartman, 1936

\section{Family and Species}

\section{Phyllodocidae}

Phyllodoce medipapillata Moore, 1909

Phyllodoce sp.

Pisionidae

Pisione cf. remota Southern, 1914

Polynoidae

Halosydna brevisetosa Kinberg, 1855

Harmothoe imbricata Linnaeus, 1767

Harmothoe multisetosa Moore, 1902

Lepidonotus sp.

Malmgreniella sp.

Sabellariidae

Sabellaria gracilis Hartman, 1944

Sabellidae

Chone mollis Bush, 1905

Megalomma pigmentum Reish, 1963

Scalibregmatidae

Scalibregma californicum Blake, 2000

Serpulidae

Hydroides elegans (Haswell, 1883)

Placostegus $\mathrm{sp}$

Sigalionidae

Sigalion spinosus (Hartman, 1939)

Sthenelais tertiaglabra Moore, 1910

Spionidae

Apoprionospio pygmaea Hartman, 1961

Laonice nuchala Blake, 1996

Microspio pigmentata Reish, 1959

Microspio spinosa Blake, 1996

Minuspio lighti Maciolek, 1985

Paraprionospio pinnata Ehlers, 1901

Polydora websteri Hartman, 1943

Prionospio (Prionospio) steenstrupi Malmgren, 1867

Spiophanes bombyx Claparède, 1870

Spiophanes duplex Chamberlain, 1919

Spiophanes kroyeri Grube, 1860

\section{Sternaspidae}

Sternaspis fossor Stimpson, 1854

Syllidae

Brania californiensis Kudenov \& Harris, 1995

Ehlersia heterochaeta Moore, 1909

......continued 
TABLE 3 (continued)

Family and Species

\section{Syllidae}

Eusyllis habei Imajima, 1966

Exogone breviseta Kudenov \& Harris, 1995

Exogone lourei Berkeley \& Berkeley, 1938

Pionosyllis articulata Kudenov \& Harris, 1995

Pionosyllis sp.

Sphaerosyllis californiensis Hartman, 1966

Sphaerosyllis $\mathrm{sp}$

\section{Family and Species}

\section{Terebellidae}

Eupolymnia heterobranchia (Johnson, 1901)

Lanassa gracilis Moore, 1923

Lanassa venusta venusta (Malm, 1874)

Pista moorei Berkeley \& Berkeley, 1942

Pista sp. 1

\section{Trichobranchidae}

Terebellides californica Williams, 1984

Terebellides sp.
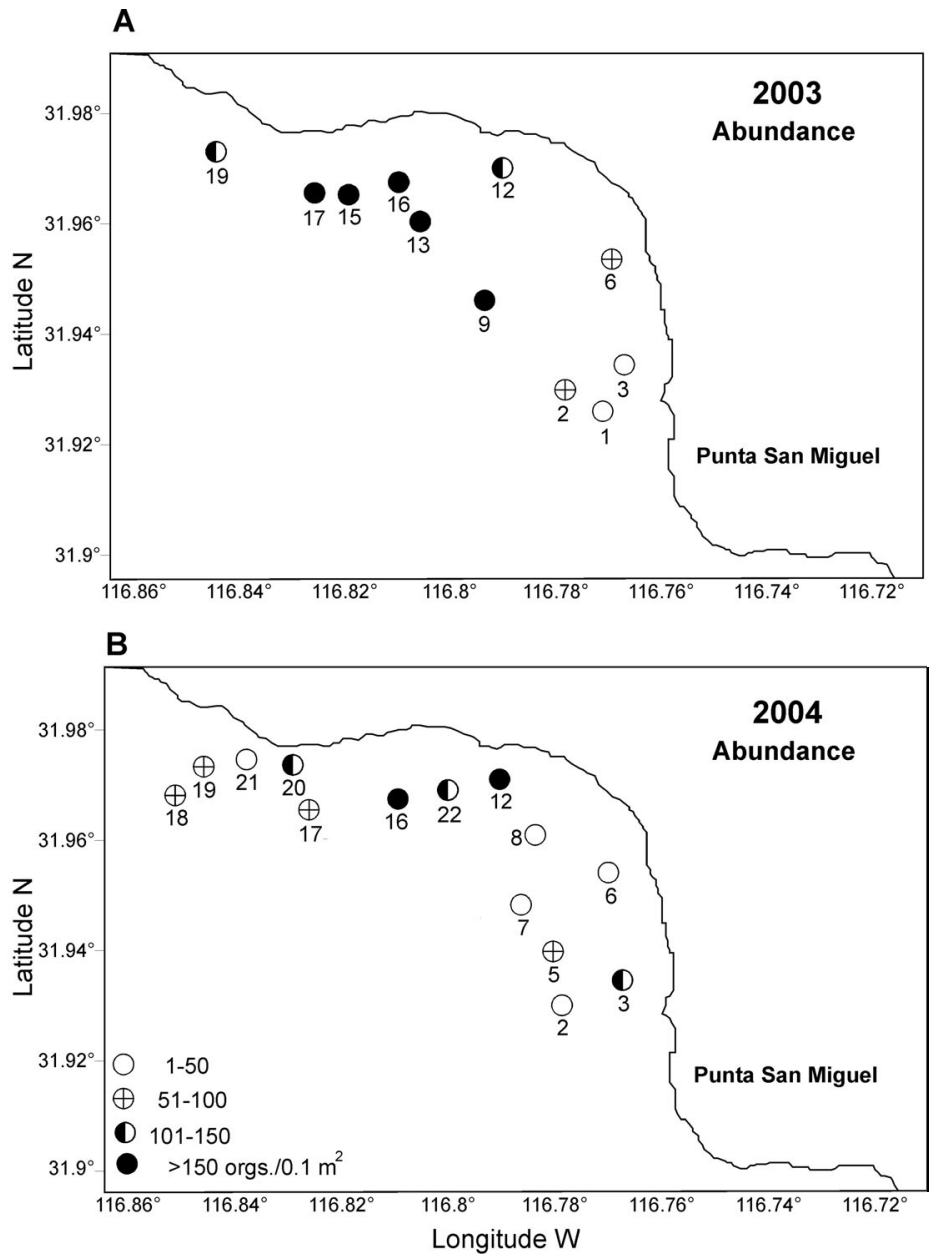

FIGURE 4. Polychaete abundance in both surveys (2003-2004). 
The best represented families in Bahía Salsipuedes were Spionidae, Cirratulidae, Paraonidae, Capitellidae, Nephtyidae, Lumbrineridae, Syllidae, and Glyceridae (Fig. 4). Some groups had higher abundances in 2004: deposit-feeding polychaetes (Cirratulidae, Spionidae, Capitellidae, Paraonidae), Decapoda, Amphipoda, Ostracoda, and Holothuroidea.

Considering 2003 and 2004 together, the families with the highest species richness were Paraonidae (14 spp.), Spionidae (11 spp.), Onuphidae (11 spp.), Maldanidae (10 spp.), Syllidae (9 spp.), and Cirratulidae and Ampharetidae with 7 species each. Species with greatest abundances were Spiophanes duplex, S. bombyx, Paraprionospio pinnata, Prionospio steenstrupi, Levinsenia gracilis, Paraonella sp., Aricidea ramosa, A. wassi, Aphelochaeta multifilis, Monticellina siblina, Monticellina sp., Chaetozone senticosa, and Mediomastus ambiseta. Fourteen species of Paraonidae were found: Aricidea alisetosa, A. catherinae, A. lopezi, A. pacifica, A. quadrilobata, A. simplex, A. antennata, A. ramosa, A. wassi, Paradoneis sp., Cirrophorus furcatus, Levinsenia oculata, $L$. gracilis, and Paraonella sp.

In 2003 and 2004, 109 and 94 species were collected, respectively. This bay exhibited a broad range of species richness per station. Values varied between 11 and 32 species in 2003 and 7 and 29 species in 2004. Higher species richness values were found mainly in the middle and southern sections of the bay.

\section{Abundance}

Polychaete abundances in 2003 ranged from 212 to 470 ind. $/ 0.1 \mathrm{~m}^{2}$ while in 2004 they varied between 90 and 225 ind./0.1 m². Fig. 4 shows a significant decrease in abundances in 2004, particularly in the northern section of the bay. Densities were dominated generally by polychaetes, followed by crustaceans, mollusks, and echinoderms.
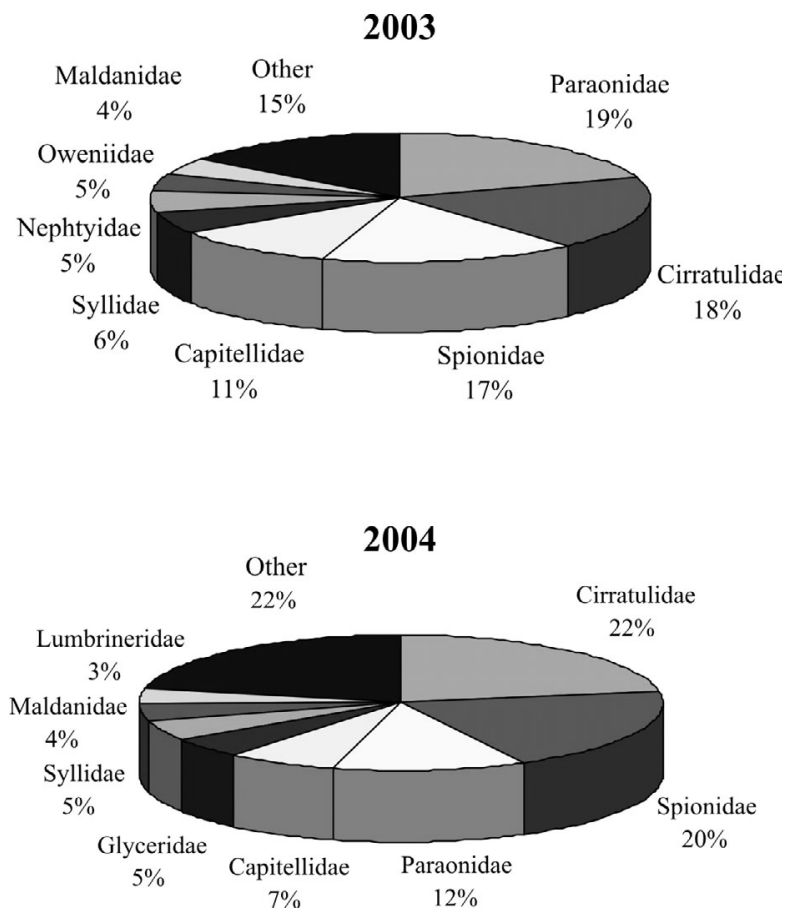

FIGURE 5. Dominance of polychaete families at Salsipuedes Bay 
In 2003, six dominant families accounted for $70 \%$ of total polychaete abundance (Fig. 5). Paraonidae, Cirratulidae, Spionidae, and Capitellidae had densities of $212-470$ ind./ $/ 0.1 \mathrm{~m}^{2}$. Stations $12,13,15,16,17$, and 19 located in the north of the bay presented the highest abundances: 133-635 ind./0.1 $\mathrm{m}^{2}$. Stations 16 and 17 located south of the tuna pens presented the highest abundance values, reaching up to 635 ind./ $/ 0.1 \mathrm{~m}^{2}$. The lowest values were found in the south, where stations $1-$ 3 and 6 had $25-97$ ind. $/ 0.1 \mathrm{~m}^{2}$; the sediment fine fraction on average was $17.4 \%$.

In 2004, seven families represented $64 \%$ of the total abundance. Cirratulidae, Spionidae, Paraonidae, and Capitellidae presented the highest abundance values, which varied between 90 and 225 ind. $/ 0.1 \mathrm{~m}^{2}$. Stations 3, 12, 16, 19, and 22, mainly located in the north near the tuna pens (except Sta. 3) presented medium and high densities: $25-98$ ind. $/ 0.1 \mathrm{~m}^{2}$. Abundance values in 2004 were lower than in 2003.

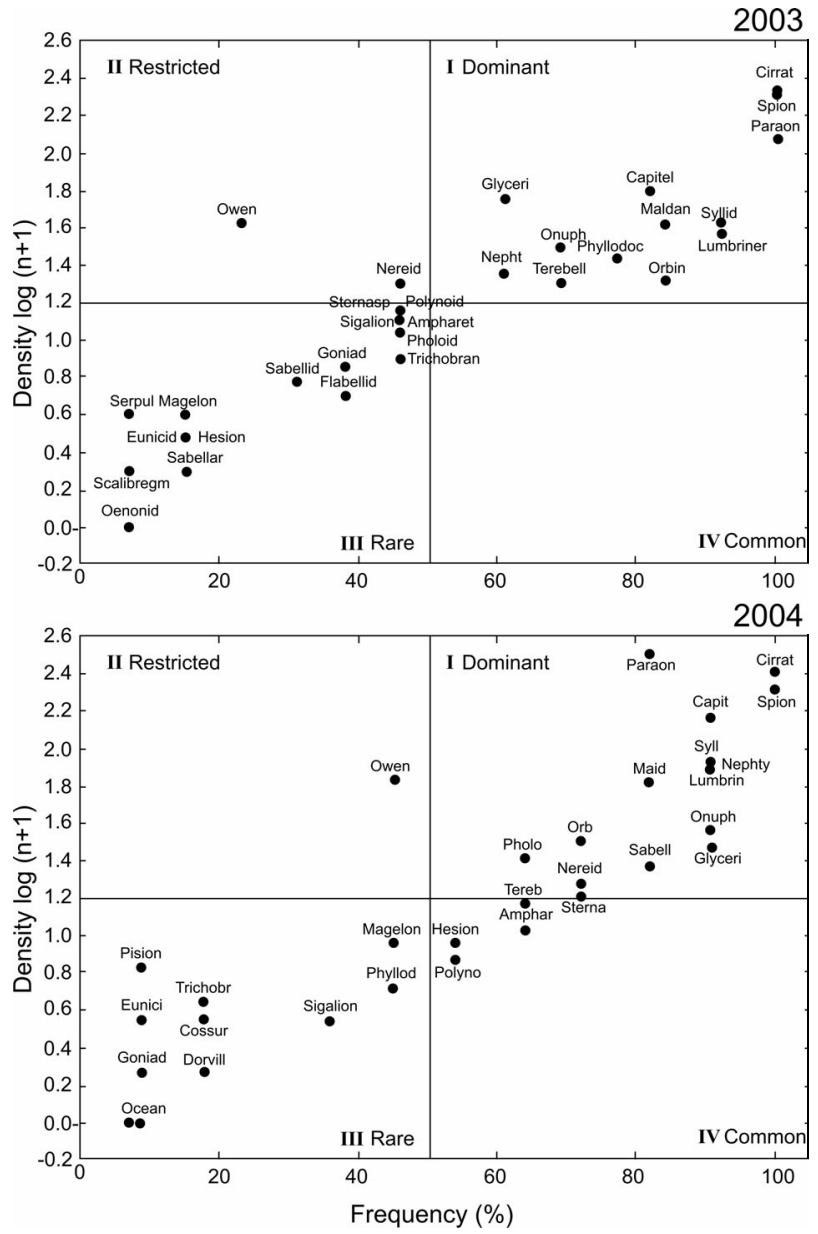

FIGURE 6. Olmstead and Tukey's analysis placed polychaetes families into three quadrants corresponding to I dominant, II restricted, III rare and IV Frequent and nonabundant. 
Olmstead and Tukey graphs, based on abundance and frequency of occurrence of polychaete families, indicated a total of 13 families as dominants in 2003 and 2004 (Fig. 6). In 2003, the 30 polychaete families were assigned to one of four possible categories: dominant (quadrant I), restricted (II), rare (III) or common (IV). In quadrant I (frequent and abundant), 13 polychaete families were characterized as dominant. Paraonidae, Spionidae, Cirratulidae, Capitellidae, and Syllidae displayed high densities and wide distribution throughout the bay. In quadrant II (restricted) there is one family Oweniidae. In quadrant III (non-frequent and non-abundant), there are 10 families, among the best represented were the Magelonidae, Phyllodocidae, and Sigalionidae. Finally, in quadrant IV (frequent and non-abundant) we have four families: Sternaspidae, Ampharetidae, Hesionidae, and Polynoidae.

In 2004 the 31 families collected were assigned to three out of the four possible categories (Fig. 6). In quadrant I (dominant), 13 polychaete families including Cirratulidae, Spionidae, Paraonidae, Glyceridae, Maldanidae, Syllidae, and Lumbrineridae displayed high densities and wide distribution throughout the bay. Two families were assigned to quadrant II: Oweniidae and Nereididae, which were restricted to certain areas of the Salsipuedes Bay (mainly in the south). Quadrant III included 16 families; the Polynoidae, Sternaspidae, Sigalionidae, Ampharetidae, Pholoidae, and Trichobranchidae presented some of the highest densities.

\section{Diversity}

In 2003 values of the Shannon index ( $\left.\mathrm{H}^{\prime}\right)$ varied between 2.26 and 3.40 bits/ind (Fig. 7). In the southern section of the bay the Shannon index varied between 2.79 and 3.40; the lowest value was found in the south, at station 5. Highest diversity values were located at stations 2 and 9, also in the south but farther from the coast; lowest $\mathrm{H}^{\prime}$ values, 2.26 and 2.54, were found at stations 16 and 17 in the north (south of tuna pens). In 2004 the Shannon index varied between 2.31 and 3.35; the highest values were found in the northern section of Salsipuedes bay (stations 8, 12 and 17) situated south of the tuna pens, while the lowest values were found at stations 18,19 , and 21 , located west of the tuna pens. In 2003 and 2004, 62\% and 42.8\%, respectively, of the stations presented a Shannon diversity value higher than 3.00, indicating Salsipuedes is still a relatively adequate environment for polychaete development.

\section{Stress-predictability modeling}

Values of species diversity $\left(\mathrm{H}^{\prime}\right)$ and evenness $\left(\mathrm{J}^{\prime}\right)$ were analyzed and placed into four "environments" (Fig.7) as defined by the stress-predictability modeling. In 2003 environment I, which included six stations $(1,2,3,7,9,13)$ with the highest values of diversity (3.11-3.40) and evenness ( $\left.\mathrm{J}^{\prime}\right)$ (0.84-0.93), was characterized as being very favorable and stable. Environment II (stations 5, 6, 12, $15,19)$, situated in the south, middle, and northwest of the bay, was favorable and stable, with $\mathrm{H}^{\prime}$ values that ranged between 2.74 and 3.09, and $\mathrm{J}^{\prime}$ values that ranged between 0.74 and 0.86 . Environment III (stations 16, 17), located in the north (south of the tuna pens) where H' values were 2.26 and 2.57 and $\mathrm{J}^{\prime}$ values were 0.75 and 0.72 , respectively, was characterized as being constant, with a degree of environmental stress. In 2004 environment I included only three stations $(8,12,17$, located south of the tuna pens) with the highest $\mathrm{H}^{\prime}$ values (3.24-3.35) and evenness J' (0.84-0.90); this environment was characterized as being very favorable and stable. Environment II was represented by eight stations $(2,3,5,6,7,16,20,22)$ located in the south (stations 2-7) and north $(16,20,22)$; it was characterized as favorable and stable with $\mathrm{H}^{\prime}$ values that ranged between 2.71 and 3.10 and J' values that ranged between 0.81 and 0.90 . Environment III was characterized as being constant, with a degree of environmental stress, and included stations 18, 19, and 21 located in the northwest of the bay; these stations had H' values of 2.48-2.31 and J' values of 0.79-0.86). In 2003 
and 2004 no stations were found in environment IV, which corresponds to moderately favorable, with unstable conditions and a certain degree of environmental stress.
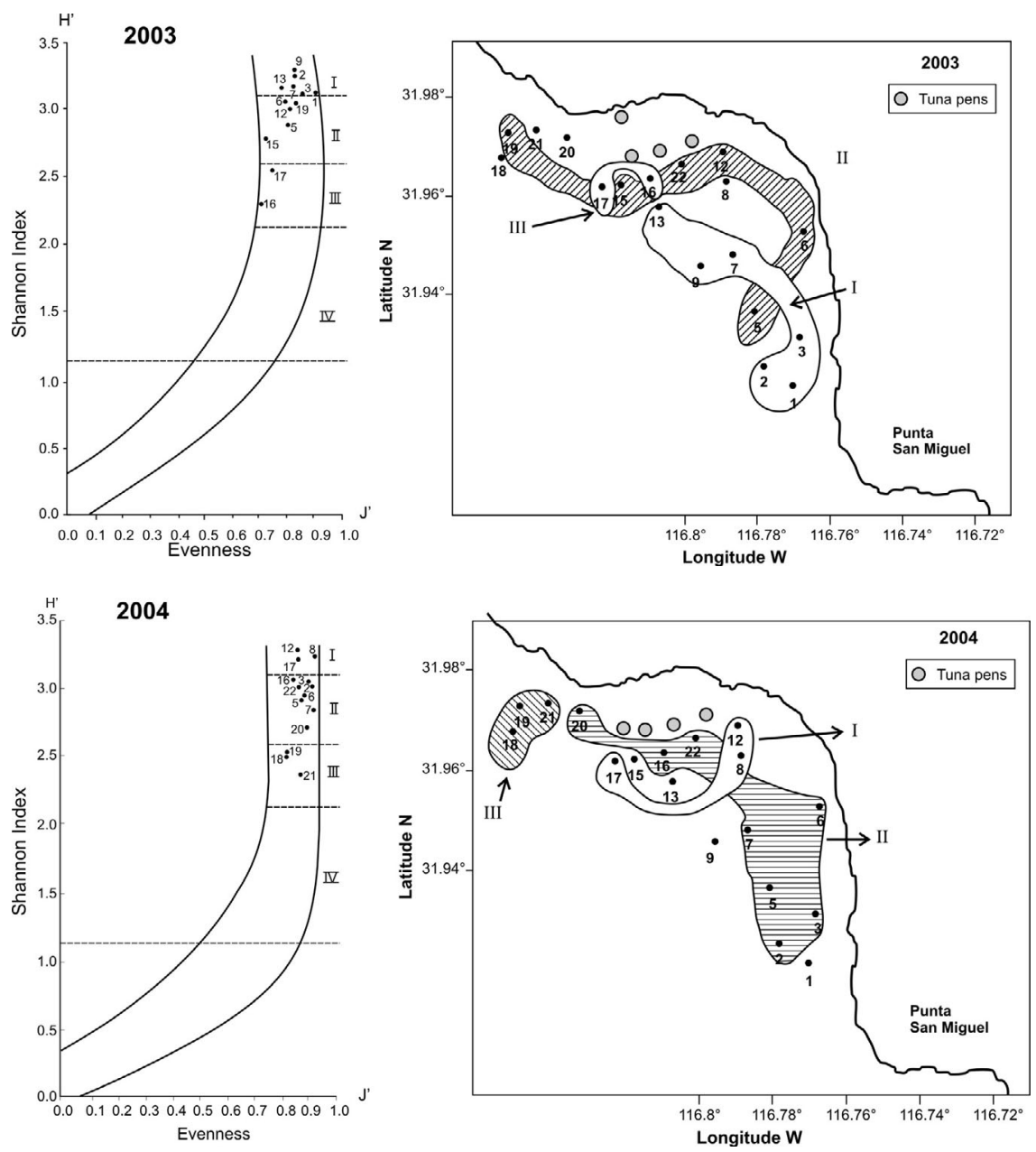

FIGURE 7. Stress-predictability modeling (Alcolado, 1992) in Salsipuedes Bay. Stations are located in three different environments: I Very favorable and stable, II favorable and stable, III constant with a degree of environmental stress.

\section{Trophic group composition}

We found that in 2003 deposit feeders and carnivores were collected from all sampling sites. In relation to polychaetes, deposit feeders were dominant, constituting between $66 \%$ and $83 \%$ of the polychaete fauna, followed by carnivores (17\%-24\%, except station 3, which had $70 \%$ carnivores) and suspension feeders (1\%-9\%). In 2004, we found that deposit feeders were also present at all sampling sites with abundances varying between $56 \%$ and $80 \%$. At stations 16, 17, and 19 (south and northwest of the tuna pens), they were best represented, reaching $72-80 \%$ of the polychaete fauna 
Carnivores varied between $20 \%$ and $44 \%$, being best represented in stations 3, 5, 6, 7, and 12 (mainly in the southern section). Suspension feeders were present at only five stations $(3,8,12,16$, and 22), where they accounted for $1 \%-4 \%$ of the polychaete fauna .

By far the dominant trophic group corresponds to surface and subsurface deposit feeders, which exploit organic matter and its associated bacterial populations. Considering that polychaetes play a key role in the energy flow within the trophic web, their abundance and species composition can influence the entire trophic structure of the bottom system in Salsipuedes Bay.

\section{Similarity}

The similarity in polychaete composition between samples was measured with the Sorensen, Jaccard, and Bray-Curtis similarity coefficients. Generally the results separated stations from the southern and northern sections of the bay. When applied to each survey separately, each algorithm separated stations in relation to sediment particle size, depth, and location in the bay (distance from tuna pens).

The cluster analysis based on the Bray Curtis coefficient with data from both surveys (Fig. 8) showed no clear division between 2003 and 2004 but essentially a separation between tuna pen stations 20 and 22 and the North 2003 and the other three groups. Five groups of stations were evident: group A includes stations 2, 6, 7, 9, 12, 18, and 19 from 2003, located in both the south and north areas of the bay; group B was formed by stations $6,8,13,15,16,17$ (as well as two replicates from stations 16 and 17) from 2003 and mostly all located in the north (south of the tuna pens), group C included stations 1, 2, 3, 5, and 7 from 2004, all located in the south, and group D comprised stations $12,16,17,18,19$, and 21 as well as a replicate: $17 \mathrm{R}$, also from 2004 , situated in the north (near the tuna pens) with higher fine fraction and organic carbon content. Finally, group E included only stations 20 and 22 from 2004, located in the northern section of the bay, near the tuna pens (these stations had $29 \%$ and $59 \%$ fine fraction $<63 \mu \mathrm{m}, 0.62$ and $0.75 \%$ organic $\mathrm{C}$ respectively); to the left we observe the outlier 20R.

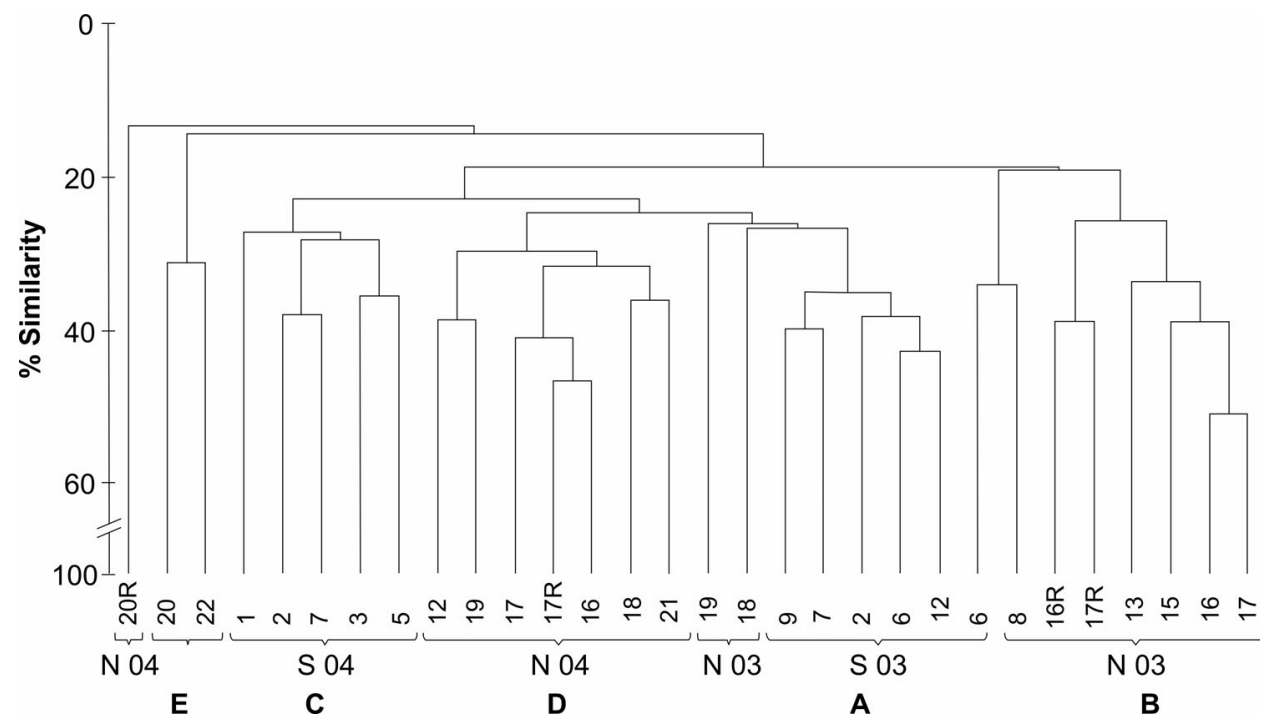

FIGURE 8. Bray-Curtis dendrogram showing classification of stations sampled in 2003 and 2004. S: south of the bay, N: north of the bay. 
The nonmetric MDS analysis performed at family (Fig. 9a) and species levels (Fig. 9b) revealed that the similarity of polychaete community structure depends on the location on the bay. Sampling sites were well classified together, based on their distances to the tuna cages. At species level we acknowledge a separation between southern and northern stations, those at the north being nearer the tuna pens. Stress values (0.05-0.17) indicate that the configurations are good representations of the faunistic similarities between stations. MDS analysis corroborated results from the dendrograms, confirming the separation of stations from the north (tuna pens location) and south of Salsipuedes Bay.

Principal component analysis (PCA) was applied to estimate the influence of abiotic variables in the polychaete community. Three principal components explained a variance of $79.8 \%$. The first three axes accounted for $34.7 \%, 22.8 \%$, and $22.3 \%$, respectively (Fig. 10). The PCA (axes 1-3) showed that polychaete abundance and biomass are mainly determined by organic $\mathrm{C}$ and $\mathrm{N}$ content, dissolved oxygen, sediment fine fraction and redox potential.
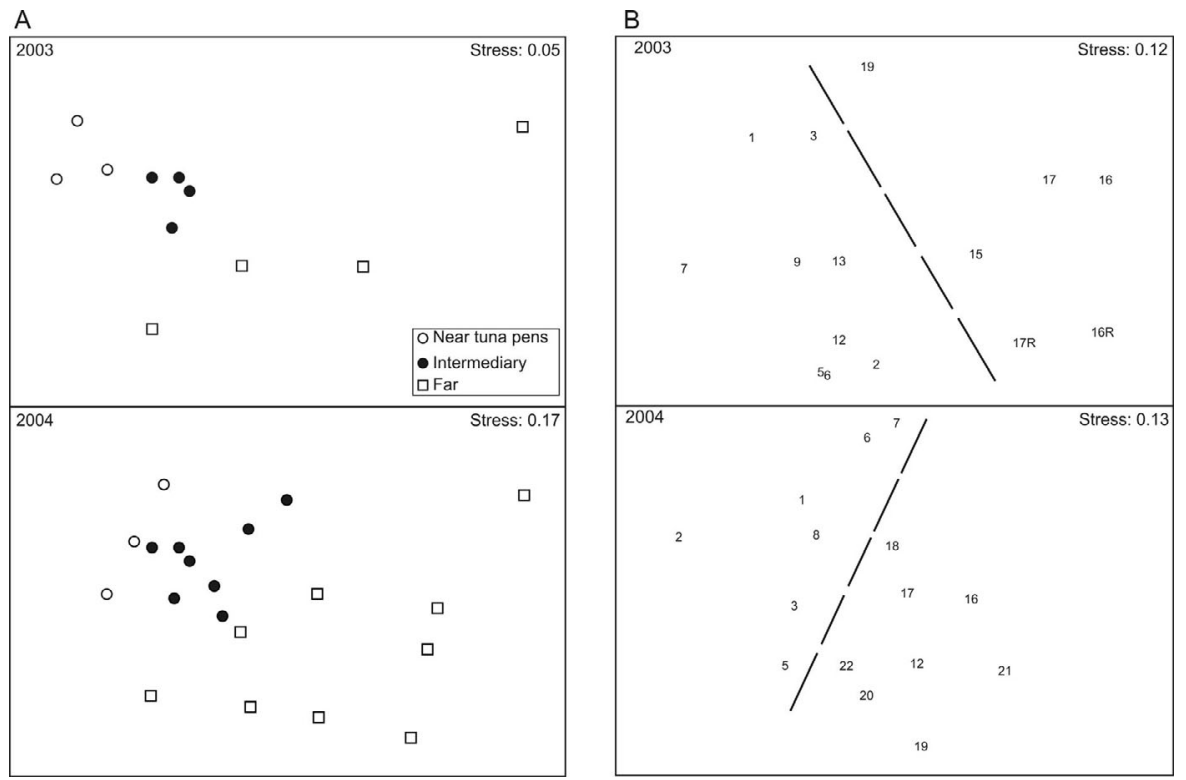

FIGURE 9. Non-metric MDS analysis of polychaetes fauna from Salsipuedes Bay. A, Family level; B, Species level. Symbols correspond to different distances from the tuna pens.

\section{Discussion}

There are no previous published studies about the polychaete fauna of Salsipuedes Bay yet the evaluation of tuna mariculture impacts needs to be contrasted with baseline information. Polychaetes in Salsipuedes were characterized by a relatively diverse composition: 34 families and 146 species were found in both surveys (2003-2004), see Tables 2-3. In Todos Santos Bay, which is adjacent to Salsipuedes, we reported 44 polychaete families and 203 species (Rodríguez-Villanueva et al., 2000; Díaz-Castañeda \& Harris, 2004), while in Barra de Navidad in Jalisco, Rodríguez-Cajiga (1993) collected 26 families and 35 species and in Magdalena bay located in Baja California Sur we 
collected 25 polychaete families and 86 species (Díaz-Castañeda \& de León-González, 2007). In San Quintin Bay we found 28 families and 104 species (Díaz-Castañeda et al., 2005). Morales \& Alfaro (2007) reported 29 polychaete families in Isla Culebra, Puerto Rico, in a fish farm area; the best represented families were Spionidae, Capitellidae, Syllidae, Glyceridae, Lumbrineridae, Nereididae, and Magelonidae. The first five families were also dominant in the present study. The diversity of families and species found at Salsipuedes Bay may be explained by a combination of factors such as abundance of organic matter, heterogeneous sediments in some areas (availability of microhabitats), high hydrodynamics, and upwelling, which all together seem to promote species richness.

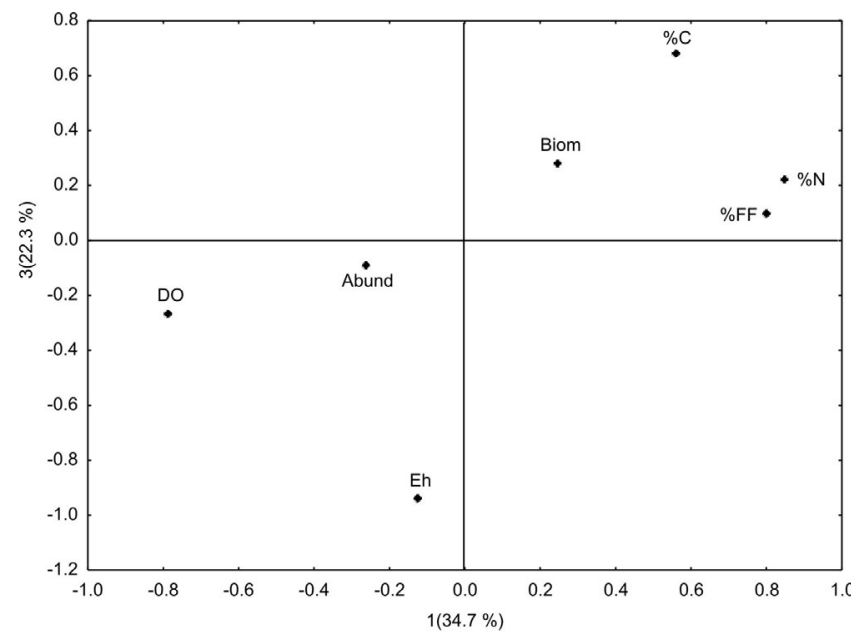

\begin{tabular}{|lccc|}
\hline & Factor 1 & Factor 2 & Factor 3 \\
Dissolved $\mathrm{O}_{2}$ & $\mathbf{- 0 . 7 8 3 0 5 5}$ & 0.072485 & -0.262106 \\
Eh $(\mathrm{mV})$ & -0.121073 & -0.089689 & $\mathbf{- 0 . 9 3 7 1 6 7}$ \\
$\%$ org C & 0.560328 & 0.065780 & $\mathbf{0 . 6 8 4 0 8 8}$ \\
$\%$ org N & $\mathbf{0 . 8 4 8 2 9 3}$ & -0.217500 & 0.223068 \\
$\%$ Fine fraction & $\mathbf{0 . 8 0 3 3 6 3}$ & 0.294928 & 0.100447 \\
Abundance & -0.257942 & $\mathbf{0 . 8 6 4 1 3 1}$ & -0.086106 \\
Biomass & 0.249127 & $\mathbf{0 . 8 3 8 0 4 6}$ & 0.283508 \\
Explained variance & 2.435392 & 1.601362 & 1.562596 \\
Proportion of total variance & 0.347913 & 0.228766 & 0.223228 \\
\hline
\end{tabular}

FIGURE 10. Principal Component Analysis ordination plot defined by axes 1 and 3 .

In Salsipuedes Bay diversity ( $\left.\mathrm{H}^{\prime}\right)$ values ranged from 2.26 to 3.40 (2003) and 2.31 to 3.35 (2004); at Todos Santos Bay, a larger and more protected bay, diversity values ranged from 2.06 to 4.80 and higher diversity values were found in the southern section of the bay (Díaz-Castañeda \& Harris 2004). Higher diversity was also found during 2003 in Salsipuedes, when the tuna farm had been in operation for less than one year. In Salsipuedes, $62 \%$ of stations had a Shannon index value higher than 3.00 in 2003 , while only $43 \%$ of stations had values $>3.0$ in 2004 . The abundance of polychaetes also decreased in 2004; this could be partially due to the fact that samples were collected in different seasons (spring 2003 and autumn 2004), however that decrease has not been observed in nearby Todos Santos Bay. 
In 2003 and 2004, 109 and 94 species, respectively, were collected. These values indicate that this bay is still a relatively adequate environment for polychaetes, although we acknowledge a reduction in the number of species collected in 2004, probably due to a decrease in species that are not able to tolerate low Eh values and eutrophication. It is important to mention that carnivorous polychaetes that could consume polychaetes and other invertebrates increased in 2004.

The analysis of trophic structure is essential to understand energy flow in marine sediments. In the present study, surface and subsurface deposit feeders were dominant, followed by carnivores (exploiting the abundance of opportunistic deposit-feeders) and suspension-feeders (which predominated in coarser sediments). Trophic relationships are particularly influenced by organic input, and changes in trophic structure may, therefore, be considered as essential to any analysis of community change in relation to such inputs to the benthos. Food supply is a key factor structuring marine benthic communities (Pearson \& Rosenberg 1978, 1987; Wieking \& Kröncke 2005), so if this rain of organic matter continues we expect to continue to detect changes in the composition and structure of the benthos in Salsipuedes Bay.

Higher abundances were correlated with medium and fine-silty sediments, which also had higher concentrations of organic matter and by 2004 were nearer the tuna pens, where paraonids, spionids, capitellids, cirratulids, and maldanids were proliferating. Different burrowing species of cirratulids, maldanids, and magelonids were well represented. Suspension feeders and carnivores were generally more abundant in the southern coastal stations that had less fine fraction due to the hydrodynamics of the area. In 2004 the abundance of suspension feeders decreased, probably in response to high turbidity and an excess of POM (particulate organic matter) in the water mass that clogged their respiratory system.

In 2003 higher diversity values were located mainly in the middle of the bay (except stations 2 and 3), in 2004 higher diversity was recorded mainly south of the tuna pens. As the tuna mariculture began in summer 2002, apparently organic matter is still "favorable," not yet having caused important negative effects, although Eh values are already negative.

Good circulation near the coast probably explains some low diversity values. In 2004 the lowest $\mathrm{H}^{\prime}$ values were found at stations 18,19 , and 21 , possibly correlated with very negative Eh values and excess organic matter (highest $\mathrm{C}$ concentration and lowest Eh were found at station 18).

Apparently bluefin tuna feeding techniques are contributing to an increase in organic matter in the area, detected by increasing negative redox potential values through time. Nevertheless, strong winds at the study area have been reported to produce surface currents with velocities of up to $10 \mathrm{~cm} /$ sec (Tapia et al. 2001) which seem to play an important role in decreasing pollution.

We know the benthic fauna plays an important role in the supply as well as mineralization of organic matter. Suspension feeders link the pelagic and the benthic environment, while benthic deposit feeders redistribute organic matter deposited on the sediment surface by sediment reworking, and oxidize the sediment by ventilation (Aller 1982). Mineralization is often enhanced significantly by macrofauna, particularly polychaetes (Banta et al. 1999).

The presence of polychaetes (particularly deposit feeders) and bioturbation should enhance sediment metabolism. It is important to maintain macrofaunal populations in tuna-farm sediments to enhance decomposition of organic matter and to prevent accumulation of organic wastes below and near the tuna cages (Heilskov \& Holmer 2001).

It seems that up to 2004 the organic matter arriving to the seabed together with the good circulation (waves, tides, currents) in the area has allowed the development of macrobenthos, particularly polychaetes, through enhanced availability of food, especially for deposit feeders, which have increased, and are not yet showing pronounced negative effects. 


\section{Conclusions}

Salsipuedes Bay hosts a relatively rich annelid fauna of which polychaetes are the most important macrofauna group in terms of abundance and number of species, being extensively distributed in this bay. Polychaete species able to proliferate after an increase in organic matter (opportunistic spionids, paraonids, cirratulids, and capitellids) play an important role in determining the structure of these communities. MDS analysis revealed that the similarity of polychaete community structure depended on the distance from tuna pens.

In this study we detected a moderate impact, probably because the nearest we could sample from tuna pens was $250 \mathrm{~m}$, sediments were sieved with a $1-\mathrm{mm}$ mesh, it is an open bay and the hydrodynamics of the area are favorable.

However, this study shows that in the northwest area of Salsipuedes Bay organic carbon and nitrogen are being accumulated (higher concentrations and lower Eh values) and smaller r-selected or opportunistic species are increasing rapidly near the tuna pens. In 2007, when we could get near the tuna pens, we found Capitella spp., which is an indicator "complex of species" associated worldwide with organically enriched areas (Díaz-Castañeda \& Reish 2009). It is essential to maintain "healthy" macrofaunal populations at Salsipuedes Bay in order to enhance decomposition of organic matter and to prevent its excessive accumulation.

\section{Acknowledgements}

We would like to thank the crew of O/V Francisco de Ulloa (CICESE). We also wish to express our gratitude to J.A. de León for assistance in the identification of some specimens and W. Daessle for help with granulometry analysis and organic C and N analysis in 2004. J. Domínguez and F. Ponce helped with the preparation of figures.

\section{References}

Alcolado, M.P. (1992) Sobre la interpretación del ambiente marino mediante el empleo de los índices de diversidad y equitatividad. Ciencias Biológicas, 24, 124-127.

Aller, R.C. (1982) The effects of macrofauna on chemical properties of marine sediment and overlying water. In: McCall, P.L. \& Tevez, M.J.S. (Eds.), Animal-Sediment Relation: The Biogenic Alteration of Sediments, Plenum Publishing Company, pp. 53-102.

Banta, G.T., Holmer, M., Jensen, M.J. \& Kristensen, E. (1999) The effect of two polychaete worms, Nereis diversicolor and Arenicola marina, on decomposition in an organic-poor and an organic-enriched marine sediment. Aquatic Microbial Ecology, 9, 189-204.

Blake, J. (1995) Family Sigalionidae. In: Blake, J.A., Hilbig, B. \& Scott, P. (Eds.), Taxonomic Atlas of the Benthic Fauna of the Santa Maria Basin and Western Santa Barbara Channel, Vol. 5. Santa Barbara Museum of Natural History, Santa Barbara, CA, pp. 189-206.

Blake, J.A. \& Hilbig, B. (Eds.) (1994) Taxonomic atlas of the Benthic Fauna of the Santa Maria Basin and Western Santa Barbara Channel, Vol. 4, The Annelida Part 1, Oligochaeta and Polychaeta: Phyllodocida (Phyllodocidae to Paralacydoniidae). Santa Barbara Museum of Natural History, Santa Barbara, CA, 377 pp.

Blake, J.A., Hilbig, B. \& Scott, P.H. (Eds.) (1995) Taxonomic Atlas of the Benthic Fauna of the Santa Maria Basin and Western Santa Barbara Channel, Vol. 5, The Annelida Part 2, Polychaeta: Phyllodocida (Syllidae and Scale-Bearing Families), Amphinomida, and Eunicida. Santa Barbara Museum of Natural History, Santa Barbara, CA, 378 pp. 
Bray, J.R. \& Curtis, T. (1957) An ordination of the upland forest communities in southern Wisconsin. Ecological Monographs, 27, 325-349.

Byers, S.C., Mills, E., \& Stewart, P. (1978) A comparison of methods to determine organic carbon in marine sediments with suggestions for a standard method. Hydrobiologia, 58, 43-47.

Clarke, K. (1993) Non-parametric multivariate analyses of changes in community structure. Australian Journal of Ecology, 18, 117-143.

Clarke, K. \& Warwick, R.M. (1994) Change in marine communities: an approach to statistical analysis and interpretation. Plymouth Marine Laboratory, Plymouth, U.K., 144 pp.

Dean, W. (1974) Determination of carbonate and organic matter in calcareous sediments and sedimentary rocks by loss on ignition: comparison with other methods. Journal of Sediment Petrology, 44, 242-248.

Díaz-Castañeda, V. \& Harris, L. (2004) Biodiversity and structure of the polychaete fauna from soft bottoms of Bahia Todos Santos, Baja California, Mexico. Deep-Sea Research II, 51, 827-847.

Díaz-Castañeda, V., de León González, J.A. \& Solana Arellano, E. (2005) Structure and composition of the Polychaete Community from Bahia San Quintín, Pacific Coast of Baja California, Mexico. Bulletin of the Southern California Academy of Sciences, 104, 75-99.

Díaz-Castañeda, V. \& de León González, J.A. (2007) Comunidades de anélidos poliquetos de Bahía Magdalena. In: Bahía Magdalena: Estudios Ecológicos, R. Funes \& J. Gutiérrez (Eds.) Instituto Politécnico Nacional, 91-100.

Díaz-Castañeda, V. \& Reish, D. (2009) Polychaetes in Environmental Studies. In: Shain, D. (Ed.), Annelids as Model Systems in the Biological Sciences. J. Wiley \& Sons, pp. 205-227.

Enell, M. (1995) Environmental impact of nutrients from Nordic fish farming. Water Science and Technology, 31, 61-71.

Fauchald, K. (1977) The polychaete worms. Definitions and keys to the orders, families and genera. Natural History Museum of Los Angeles County, Science Series, 28, 1-188.

Fauchald, K. \& Jumars, P. (1979) The diet of worms: a study of polychaete feeding guilds. Oceanography and Marine Biology: An Annual Review, 17, 193-284.

Frontier, S. (1985) Diversity and structure in aquatic ecosystems. Oceanography and Marine Biology: An Annual Review, 23, 253-312.

Grall, J. \& Chauvaud, L. (2002) Marine eutrophication and benthos: the need for new approaches and concepts. Global Change Biology, 8, 13-830.

Gray, J., Clarke, K.R., Warwick, M. \& Hobbs, G. (1990) Detection of initial effects of pollution on marine benthos: An example from the Ekofisk and Eldfisk oilfields, North Sea. Marine Ecology Progress Series, 66, 285-299.

Hall P.J., Holby, O., Kollberg, S. \& Samuelsson, M. (1992) Chemical fluxes and mass balances in a marine fish cage farm. IV. Nitrogen. Marine Ecology Progress Series, 89, 81-91.

Hedges, J.I. \& Stern, J.H. (1984) Carbon and nitrogen determination of carbonate containing solids. Limnology \& Oceanography, 29, 657-663.

Hilbig, B. (1994) Family Nereididae. In: Blake, J.A., Hilbig, B. (Eds.), Taxonomic Atlas of the Benthic Fauna of the Santa Maria Basin and Western Santa Barbara Channel, Vol. 4. Santa Barbara Museum of Natural History, Santa Barbara, CA, pp. 301-327.

Heilskov, A.C. \& Holmer, M. (2001) Effects of benthic fauna on organic matter mineralization in fish-farm sediments: importance of size and abundance. ICES Journal of Marine Science, 58, 427-434.

Karakassis, I., Tsapakis, M. \& Hatziyan, E. 1998. Seasonal variability in sediment profiles beneath fish farm cages in the Mediterranean. Marine Ecology Progress Series, 162, 243-252.

Karakassis, I., Tsapakis, M., Hatziyan, E., Papadopoulou, K. \& Plaiti, W. (2000) Impact of cage farming of fish on the seabed in three Mediterranean coastal areas. ICES Journal of Marine Science, 57, 1462-1471.

Knox, G. (1977) The role of polychaetes in benthic soft-bottom communities. In: Reish, D. \& Fauchald, K. (Eds.), Essays on Polychaetous Annelids in Memory of Dr. Olga Hartman. Allan Hancock Foundation, Los Angeles, CA, pp. 547-604.

Legendre, L. \& Legendre P. (1984) Ecologie Numerique. La structure des donnees ecologiques. Masson Ed-, Paris 
\& Presses Univ. Quebec, $254 \mathrm{pp}$.

Liao, I.C. \& Lin, C. (2000) Cage aquaculture in Asia. Proceedings of $1^{\text {st }}$ International Symposium on Cage Aquaculture in Asia, pp. 21-37. Asian Fisheries Society, Manila and World Aquaculture Society, Chapter Bangkok.

Morales, A. \& Alfaro, M. (2007) Ecological response of polychaetes to an open ocean aquaculture system at Isla Culebras, Puerto Rico. Poster at Ninth International Polychaete Conference, August 2007, Portland, Maine.

Pearson, T.H. \& Rosenberg, R. (1978) Macrobenthic succession in relation to organic enrichment and pollution of the marine environment. Oceanography Marine Biology: An Annual Review, 16, 229-311.

Pearson, T.H. \& Rosenberg, R. (1987) Feast and famine: structuring factors in marine benthic communities. In:

Gee J. \& Giller, P. (Eds). Organization of communities: past and present. 27 hymposium of the British Ecological Society. Blackwell Scientific Publications, Oxford, pp. 373-395.

Pielou, E.C. (1977) Mathematical Ecology. Wiley, New York, 385 pp.

PRIMER (2002) Plymouth routines in Multivariate Ecological Research. PRIMER 5 for Windows version 5.2.9. PRIMER-E, Plymouth.

Rodríguez-Villanueva, V., Díaz-Castañeda, V. \& Martínez, R. (2000) Structure and composition of the benthic polychaetes families in Bahia Todos Santos, Baja California, Mexico. Bulletin of Marine Science, 67, 113-126.

Rodríguez-Cagija, S. (1993) Macrofauna de la laguna Barra de Navidad, Jalisco. In: Salazar-Vallejo, S. \& Gonzalez, N.E. (Eds.), Biodiversidad Marina y Costera de Mexico. Comisión Nacional para la Biodiversidad y CIQRO, México, pp. 499-508.

Rojas, A. \& Wadsworth, S. (2007) A review of cage aquaculture: Latin America and the Caribbean. In: Halwart, M., Soto, D. \& Arthur, J.R. (Eds), Cage aquaculture - Regional reviews and global overview. FAO Fisheries Technical Paper 498, Rome, pp. 70-100.

Rouse, G.W. \& Pleijel, F. (2001) Polychaetes. Oxford University Press, Oxford, 354 pp.

Sakar, S.K., Bhattacharya, A., Giri, S., Bhattacharya, B. Sarkar, D., Nayak, D.C. \& Chattopadhaya, A.K. (2005) Spatiotemporal variation in benthic polychaetes (Annelida) and relationships with environmental variables in a tropical estuary. Wetlands Ecology and Management, 13, 55-67.

Salazar-Vallejo, S. \& Salaices-Polanco, H. (1989) Poliquetos (Annelida: Polychaeta) de Mexico. Universidad Autónoma Baja California Sur, La Paz, BCS México, 229 pp.

Shahidul, I.M. (2005) Nitrogen and phosphorus budget in coastal and marine cage aquaculture and impacts of effluent loading on ecosystem: review and analysis towards model development. Marine Pollution Bulletin, $50,48-61$.

Shannon, C.E. \& Weaver, W. (1963) The Mathematical Theory of Communication. University of Illinois Press, Urbana, $125 \mathrm{pp}$.

Sokal, R. \& Rohlf, F.J. (1995) Biometry. Freeman Ed., New York, 887 pp.

Tapia, F., Pineda J., Ocampo-Torres, F., Fuchs, H., Parnell, P. E., Montero, P. \& Ramos, S. (2004) High-frequency observations of wind-forced onshore transport at a coastal site in Baja California, Continental Shelf Research, 24, 1573-1585.

Wieking, G. \& Kröncke, I. (2005) Is benthic trophic structure affected by food quality? The Dogger Bank example. Marine Biology, 146, 387-400. 
